\title{
Platelet transfusion - the new immunology of an old
}

\section{therapy}

\section{Moritz Stolla ${ }^{1}$, Majed A. Refaai ${ }^{1}$, Joanna M. Heal ${ }^{1}$, Sherry L. Spinelli ${ }^{1}$, Olivier Garraud ${ }^{2}$, Richard P. Phipps ${ }^{1,3,4,5}$ and Neil Blumberg ${ }^{1 *}$}

${ }^{1}$ Department of Pathology and Laboratory Medicine, School of Medicine and Dentistry, University of Rochester Medical Center, Rochester, NY, USA

${ }^{2}$ Etablissement Francais du Sang Auvergne-Loire, Universite de Lyon, Saint-Etienne, France

${ }^{3}$ Department of Microbiology and Immunology, School of Medicine and Dentistry, University of Rochester Medical Center, Rochester, NY, USA

${ }^{4}$ Department of Environmental Medicine, School of Medicine and Dentistry, University of Rochester Medical Center, Rochester, NY, USA

${ }^{5}$ Department of Medicine, School of Medicine and Dentistry, University of Rochester Medical Center, Rochester, NY, USA

\section{Edited by:}

Heiko Mühl, University Hospital

Goethe University Frankfurt, Germany

\section{Reviewed by:}

Bo Shen, University of Illinois at Chicago, USA

Angelo A. Manfredi, Vita Salute San

Raffaele University, Italy

\section{*Correspondence:}

Neil Blumberg, Department of Pathology and Laboratory Medicine, School of Medicine and Dentistry, University of Rochester Medical Center, Box 608, 601 Elmwood Avenue, Rochester, NY 14642, USA e-mail: neil_blumberg@urmc. rochester.edu
Platelet transfusion has been a vital therapeutic approach in patients with hematologic malignancies for close to half a century. Randomized trials show that prophylactic platelet transfusions mitigate bleeding in patients with acute myeloid leukemia. However, even with prophylactic transfusions, as many as $75 \%$ of patients, experience hemorrhage. While platelet transfusion efficacy is modest, questions and concerns have arisen about the risks of platelet transfusion therapy. The acknowledged serious risks of platelet transfusion include viral transmission, bacterial sepsis, and acute lung injury. Less serious adverse effects include allergic and non-hemolytic febrile reactions. Rare hemolytic reactions have occurred due to a common policy of transfusing without regard to ABO type. In the last decade or so, new concerns have arisen; platelet-derived lipids are implicated in transfusion-related acute lung injury after transfusion. With the recognition that platelets are immune cells came the discoveries that supernatant IL-6, IL-27 SCD40L, and OX40L are closely linked to febrile reactions and SCD40L with acute lung injury. Platelet transfusions are pro-inflammatory, and may be pro-thrombotic. Anti-A and anti-B can bind to incompatible recipient or donor platelets and soluble antigens, impair hemostasis and thus increase bleeding. Finally, stored platelet supernatants contain biological mediators such as VEGF and TGF- $\beta 1$ that may compromise the host versus tumor response. This is particularly of concern in patients receiving many platelet transfusions, as for acute leukemia. New evidence suggests that removing stored supernatant will improve clinical outcomes. This new view of platelets as pro-inflammatory and immunomodulatory agents suggests that innovative approaches to improving platelet storage and pre-transfusion manipulations to reduce toxicity could substantially improve the efficacy and safety of this long-employed therapy.

Keywords: platelets, transfusion, immune response, transfusion reaction, storage, thrombosis, bleeding

\section{INTRODUCTION}

Since their discovery, platelets have displayed a remarkable development from a pro-thrombotic and pro-hemostatic cell fragment to a surprisingly versatile immune-thrombotic cell. The plethora of findings continues to surprise and excite at the same time. In concordance, an old therapy, i.e., platelet transfusion, either for prophylaxis or acute bleeding has been in transition as well. Initially thought as an "easy fix" for thrombocytopenia, platelet transfusions are now considered a double-edged sword at best. Despite all the controversies, platelet transfusions are a clinical necessity and do save lives every day worldwide. However, the majority of platelet transfusions are administered for prophylactic purposes, and for chronic conditions, rather than acute hemorrhage. It is presently unclear if platelet transfusions are effective

Abbreviations: NET, neutrophil extracellular trap; PMP, platelet microparticles; sPs, soluble P-selectin. in settings of acute hemorrhage. Moreover, the following questions are open and continue to evolve: Do platelet transfusions work the way we think? What are the downsides to this therapy? Some reports already highlight a pro-thrombotic side effect of platelet transfusion, leaving the thrombocytopenic patient, who is already at risk for bleeding with an increased risk of thrombosis and bleeding at the same time.

\section{PLATELETS - NOVEL FINDINGS IN IMMUNITY AND INFLAMMATION}

We briefly summarize a selection of the most relevant findings in regards to an inflammatory and defensive role of platelets from the recent literature.

Platelets are anucleate cell fragments, derived from megakaryocytes and circulate with an average number of 150,000$300,000 / \mu l$ in humans. Their role in thrombosis and hemostasis has been well described. Their role in inflammation, however, was 
discovered only relatively recently and has constantly been evolving ever since. From an evolutionary perspective, platelets likely originated from a versatile cell type with both strong hemostatic and defensive cell properties $(1,2)$. Their role in hemostasis is therefore closely intertwined with their sentinel and inflammatory properties. Activation of platelet surface receptors leads to inside-out signaling, which is followed by integrin activation, which in turn, is crucial for thrombus formation (3). In addition to G-protein coupled receptors (mainly protease-activated receptors, or PARs), platelets also possess immunoreceptor tyrosinebased activation motif (ITAM), e.g., Fc-receptors, glycoprotein VI, and C-type lectin-like receptor 2 (CLEC2). Fc-receptors allow for immunoglobulin and immune complex binding, while GPVI (the major collagen receptor) and CLEC2 are known to be important for vascular integrity in inflammation (4). Toll-like receptors (TLR) are present on platelets as well, although there are conflicting reports about their functionality (5-8). A recent report indicated that platelets were able to discriminate between different LPS isoforms by differential cytokine secretion by mononuclear cells, including IL-6, TNF- $\alpha$, and IL-8 (9). In addition, platelets express the coxsackievirus and adenovirus receptor (CAR). Of note, coxsackievirus 1 and 3 induced P-selectin exposure and phosphatidyl serine exposure in platelets, albeit independently of CAR. The presence of platelets led to lower coxsackievirus 1 and 3 titers, to less myocardial virus load and to better survival in mice infected with the virus. To a similar conclusion came authors of another recent paper, showing how platelets protect the host during encephalomyocarditis virus (EMCV) infection via TLR7. Platelet depletion led to reduced survival, and transfusion of WT platelets into TLR7-deficient mice improved survival and was accompanied by a drop in platelet count (10). Another virus, which has recently been described to interact with platelets, is the H1N1 influenza virus. During infection with $\mathrm{H} 1 \mathrm{~N} 1$, platelets show activation of their surface receptors, lipid mediator generation, and release of microparticles. Interestingly, immunized subjects showed circulating immune complexes of virus and IgG, which were able to activate platelets via Fc $\gamma$ RIIa. Alternatively, H1N1 virus was able to activate platelets via thrombin generation (11).

Platelets express high-mobility group protein 1 (HMGB1) (12). Upon activation, HMGB1 is translocated from the cytoplasm to the outer plasma membrane. In its extracellular location, HMGB1 has been implicated in inflammatory, proliferative, and migratory processes (13). TLR2, 4, 9, the receptor for advanced glycolation end-products (RAGE) and Mac-1 have been described in the inflammatory actions of HMGB1 (14-16), while ultimately these signals lead to NF- $\mathrm{b}$ activation. While HMGB1 has not been investigated in the context of platelet transfusion, it is entirely conceivable that HMGB1 accumulates during platelet storage and triggers inflammatory sequela upon transfusion.

We and others have demonstrated that although platelets are anucleate cell fragments they express an armamentarium of transcription factors including the NF- $\kappa b$ transcriptional regulatory system, Bcl-3, and PPAR $\gamma$ (17-22). The current concept is that these factors act in non-transcriptional ways in platelets, e.g., by modulating the response to activation, even though they act as traditional transcription factors in megakaryocytes $(17,21)$.
Although platelets do not possess a nucleus, there is evidence that platelets can synthesize IL- $1 \beta$ in substantial amounts upon activation. In a resting state, platelets contain the pre-mRNA of IL- $1 \beta$. However, when activated, they synthesize pro-IL- $1 \beta$ protein, which is further processed and ends up as the mature form of the cytokine IL-1 $\beta(23,24)$. One of the earlier discoveries in platelet biology was the tendency of platelets to "stick" to leukocytes when activated and in generalized inflammatory conditions. All subclasses of leukocytes have been described to adhere to platelets (25-27). However, the majority of studies describe myeloid leukocytes as the platelet-binding partner. The interaction between platelet and leukocyte mainly depends on the P-selectin - PSGL-1, and fibrinogen $-\alpha \operatorname{IIb} \beta 3$, or directly to GPIb and $\alpha \mathrm{M} \beta 2$ (28).

The initial contact between leukocyte and platelet is established via platelet P-selectin and leukocyte PSGL-1. On the molecular level, $\mathrm{P}$-selectin binds in a stereospecific manner to the N-terminal region of PSGL-1, by recognizing a motif with tyrosine sulfate residues, fucose, galactose, and sialic residues on a core- $2 \mathrm{O}$-glycan (29). Overall, the interaction between P-selectin and PSGL-1 has a very rapid association/dissociation rate, facilitating the rapid capture, tethering, and rolling under high flow and shear conditions (30). Of note, this initial step of tethering and rolling does not require any leukocyte activation signals, but subsequent steps of firm adhesion and transmigration require signaling events that ultimately lead to integrin activation. Specifically, Nef-associated factor 1 (Naf-1, downstream of PSGL-1) is phosphorylated by Src-family kinase (SFK), and leads to Mac-1 ( $\alpha \mathrm{M} \beta 2)$ activation. In addition, neutrophils show LFA-1 ( $\alpha \mathrm{L} \beta 2)$ activation, while monocytes and lymphocytes show $\beta 1$ and $\beta 2$ activation $(31,32)$. Integrin outside-in signaling via SFK then leads to phosphorylation of proline-rich tyrosine kinase 2 ( $\mathrm{Pyk} 2)$, which is followed by a sustained leukocyte activation with stabilization of the integrin bond and a delayed inflammatory response including NF-кb activation. Furthermore, if circulating as heterotypic aggregates, they can facilitate leukocyte deposition at sites of inflammation and vascular injury and have been described in a plethora of diseases (33-36).

Notably, platelets contain substantial amounts of CD40L (formally known as CD154), a protein with a significant role in T-cell-dependent isotype switching and generation of antibody subclasses by B-cells. Platelets can stimulate neutrophils, T-cells, and endothelial cells via CD40L (37-39). In addition to interacting with leukocytes, platelets closely interact with endothelial cells. Inflammatory conditions are usually accompanied by a certain degree of vascular leakiness. Interestingly, thrombocytopenic patients usually do not bleed with platelet counts above $10,000 / \mu 1$ unless they develop inflammation. This contributory role of platelets to vascular integrity seems to mainly depend on platelet ITAM receptors $(4,40-42)$. In a similar way, platelets seem to protect the vasculature in tumors and prevent bleeding inside of tumors $(43,44)$. Surprisingly, platelets have also been found to enhance vascular permeability during inflammation, perhaps due to their secretion of VEGF, serotonin, and other similar factors. These seemingly contradictory results might reflect model, species, and site-specific differences, but it might also depend on a differential release of mediators, specifically serotonin has been shown to be crucial for the induction of vessel permeability by platelets (45). 
How the differential contribution to vessel integrity and leakiness is regulated in vivo remains to be investigated. Examining vascular integrity during dengue virus infection, Hottz et al. found that platelets contribute to vascular leakage by releasing IL- $1 \beta$ rich microparticles after assembly of nucleotide-binding domain leucin-rich repeat containing protein (NLRP3), and are thus likely to contribute to hemorrhage frequently observed during infection with this virus (46). Other virus-induced hemorrhagic fevers also critically involve platelets (47). Recent studies also highlight the ability of platelets and platelet-like particles to transfer microRNA to leukocytes and endothelial cells. Even though this has not been shown to be the case in an inflammatory setting, it is an interesting mechanism to transfer "long distance" information and contribute to vascular homeostasis (48). An intriguing recent study by Massberg et al. suggested that platelets serve as "first sensors" for endothelial damage and potential invaders. Platelets adhered to and activated neutrophils, which in turn released nucleosomes and serine proteases in order to trigger the intrinsic and extrinsic coagulation pathway. This localized promotion of thrombosis by platelets and neutrophils in order to trap invaders in the microcirculation is a novel example of how closely intertwined innate defense mechanisms and thrombotic processes are $(49,50)$.

One of the most striking recent findings is how neutrophils produce extracellular traps, or "neutrophil extracellular traps (NETs)" in order to cause thrombosis and thereby trap invading microbes. While neutrophils are the major inducer of NETs by ejecting their nucleus, there is emerging evidence that platelets assist neutrophils in this process: platelet $\beta$-defensin- 1 released after stimulation with Staphylococcus $\alpha$-toxin was found to be critically involved in the formation of NETs under flow conditions in vitro and in vivo (51). Earlier, an elegant study by Clark et al. showed that TLR4 on platelets binds to circulating LPS and mediates neutrophilplatelet binding with subsequent neutrophil activation and NET formation in mice and humans. The authors were able to show that NET formation helped trapping bacteria. Similar to the study mentioned above by Massberg et al., platelets function as a "sensor" for circulating LPS and facilitate neutrophil activation (52). Of note, platelets were also critically involved in NET formation in a mouse model of transfusion-related acute lung injury (53, 54). A somewhat under-recognized cell organelle in platelets has recently been shown to contribute to the inflammatory response by platelets: by releasing mitochondria, either free or coated by microvesicles, they provided the substrate for secreted phospholipase $\mathrm{A}_{2}$-IIa ( $\mathrm{PLA}_{2}$-IIa), which in turn produces lysophospholipids, fatty acids, and mtDNA to activate leukocytes (55).

\section{PLATELET STORAGE AND INFLAMMATION}

Prolonged storage leads to changes in platelets mostly associated with platelet activation. Contents of the alpha granules are secreted which leads to a gradual increase in P-selectin and CD40L membrane expression. Consistently, the number of platelets attached to leukocytes increases over time during storage (56). A substantial amount of P-selectin and CD40L are shed into the plasma as soluble P-selectin (sPS) and sCD40L, respectively $(57,58)$ (Figure 1). CD40L and its interaction with neutrophils and endothelial cells have been implicated in the development of non-antibodymediated transfusion-associated acute lung injury (TRALI) (39).
Of note, platelets act in concert with T-cells to mediate B-cell stimulation and function as a "first wave" of B-cell activation (37). Specifically, after a 3-day incubation with platelets, B cells showed an increased production of IgG1, IgG2, and IgG3, but not IgG4, IgA, or IgM (37). Interestingly, activation of dendritic cells by platelets has proven to be independent of sCD40L. While platelets do stick to dendritic cells, dendritic cell activation is mediated by nucleotides like ADP and ATP (59). Platelet CD40L has also been involved in host defense against Listeria monocytogenes in a mouse model (60). In addition to its role in inflammation, platelet CD40L has also been implicated in more traditional roles of platelets such as thrombus formation and thrombus stabilization (61). In addition to P-selectin and CD40L, multiple other platelet alpha and dense granule substances are found in the supernatant: e.g., $\beta$-thromboglobulin, platelet factor 4 , and serotonin (62).

Stored platelets also exhibit an increase in phosphatidylserine (PS) exposure (Figure 1), which can be assessed via annexin $\mathrm{V}$ binding. Of note, the degree of platelet activation does not correlate with P-selectin expression, platelet count increment, or function in vivo. P-selectin-expressing platelets that were transfused into primates and rabbits rapidly lost their surface P-selectin but continued to function and to circulate in vivo (63-65).

Platelet microparticles (PMP) are released from platelets upon activation or apoptosis. Platelet concentrates contain PMPs in the supernatant, reflecting activation during collection, and/or storage (Figure 1). Apheresis collection is associated with less PMP formation when compared to platelets separated from whole blood donations $(66,67)$. PMPs have been shown to be critically involved in inflammatory conditions like rheumatoid arthritis (68). Infusion of activated platelets and microparticles causes early atherosclerotic lesions (fatty streaks) and exacerbate atherosclerosis in mice and diabetic patients (69-71). Furthermore, PMPs enable platelets to transport RNA, cytokines, or chemokines to other cells and tissues, as they are small enough to exit the circulation and to enter the surrounding tissues. This has been shown for RANTES (72), IL-1 $\alpha$ (68), IL-1 $\beta$ (24, 73), PPAR $\gamma$ (74), retinoid $\mathrm{X}$ transcription factor $(74)$, and $\operatorname{CD} 40 \mathrm{~L}(75,76)$, albeit not under transfusion conditions. Human cytomegalovirus (HCMV) activates platelets via TLR2 and triggers ADP release and subsequent platelet leukocyte aggregate formation in vitro and in vivo, which might explain how this virus might contribute to atherosclerotic lesion formation (77).

We were recently able to show that the composition of microparticles can be altered by genetic engineering. Using lentiviral technology, we introduced green fluorescent protein (GFP) and increased PPAR $\gamma$ expression in megakaryocytic cell lines and primary megakaryocytes. Platelets and microparticles generated by modified megakaryocytes were internalized by a monocytic cell line and altered the expression of a target protein of PPAR $\gamma$. This is a potentially useful tool in altering and investigating transcellular communications (78). To what extend PMP contribute to the hemostatic properties of platelet transfusions has not been yet investigated. Moreover, PMPs function as messengers to convey pro-inflammatory information to endothelial cells and leukocytes. No study has investigated the pro-inflammatory role of PMPs after transfusion yet, but it seems likely that there are some systemic effects to the recipient. Stored platelets also contain 


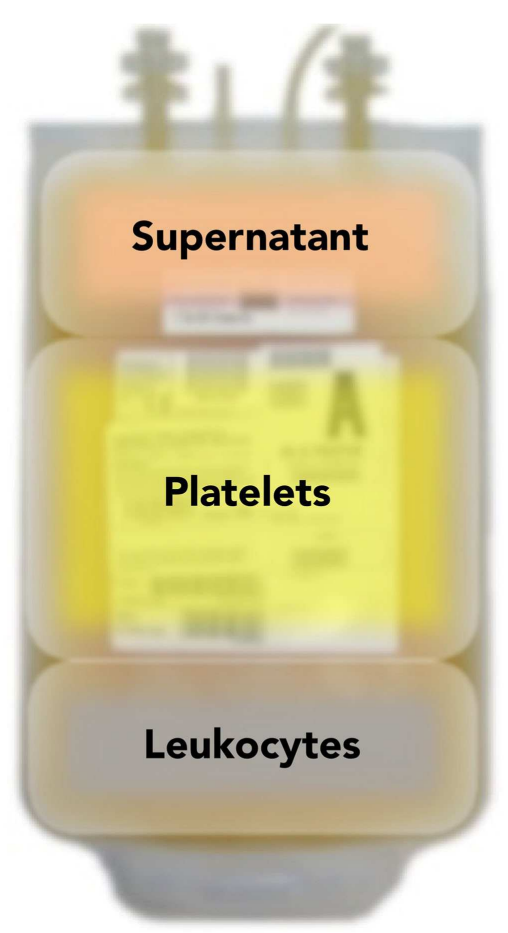

FIGURE 1 | Unwanted passengers and events during platelet storage: Besides platelets, platelet concentrates contain "unwanted passengers" in the form of soluble mediators in the supernatant (in the case of unwashed platelet concentrates - which are still the routine product in virtually all US hospitals) and leukocytes (in the case of nonleukoreduced platelet concentrates - which are still an available product in some US hospitals). The supernatant (red background) contains substances which are secreted or shed into the plasma during storage containing soluble mediators, like sCD40L, PDGF, or sP-selectin. In addition, cytokines and cell fragments can be found. The platelet themselves (yellow
Soluble mediators, growth factors, etc.

from platelet surface

and granules:

sCD40L, PDGF

sP-selectin, VEGF

$\beta$-thromboglobulin

PF4, FGF, TGF- $\beta 1$

Serotonin

sOX40L

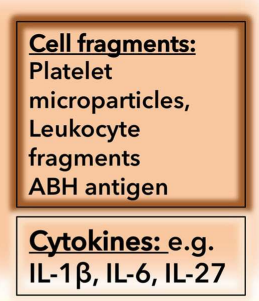

Expression of $A B O$-antigens:

ABO-unmatched platelets yield a lower

platelet increment, show shorter survival,

reduced hemostatic properties

Increased PS exposure, expression of

CD40L and P-selectin

A V Platelet-leukocyte aggregates

Alloimmunization:

Sensitization to HLA antigens expressed

on passenger leukocytes $\rightarrow$ refractoriness

to subsequent non-HLA matched platelet

transfusions

Activation of B cells by platelets minute fragments of leukocytes that have been involved in HLAsensitization and platelet refractoriness in pre-clinical studies (79) (Figure 1).

Adding some clinical relevance to the aforementioned preclinical in vitro and lab findings, we were able to show that washing red cells and platelets (i.e., removing the supernatant) is associated with less inflammatory response in high-risk pediatric populations compared to non-washed platelet transfusions (80). Furthermore, the patients in the study-arm needed fewer transfusions and there was a trend to lower mortality in the study-arm (washed units). Larger clinical trials are needed to determine if this finding is clinically significant (80).

\section{TRANSFUSION REACTIONS AND IMMUNOMODULATION}

Although platelet transfusions are generally well-tolerated, they cause more transfusion reactions than any other blood product (81). The adverse events range from simple allergic reactions to severe anaphylactic reactions, febrile-non-hemolytic reactions, transfusion-associated sepsis, and TRALI. Several strategies have been shown to reduce the rate of transfusion reactions, e.g., leukocyte reduction, washing, and $\mathrm{ABO}$ matching. As described above, background) change during storage. They become hyporesponsive (not depicted), and degranulate with increased expression of alpha granule contents (e.g., P-selectin). Platelets express ABO antigens, which lead to suboptimal results and complications if transfused into $A B O-u n m a t c h e d$ recipients. A marker for platelet activation is platelet leukocyte aggregate formation (white background). With prolonged storage, the number of platelet leukocyte aggregates increase. Leukocytes in the stored bag (gray background) release cytokines, which can induce febrile transfusion reactions Passenger leukocytes lead to sensitization to HLA antigens with subsequent refractoriness. stored platelets release sCD40L and accumulate CD40L on their surface. In fact, platelet concentrates from apheresis and whole blood collection demonstrated the highest SCD40L concentrations compared to all other blood products (39). Platelet concentrates involved in TRALI had significantly higher sCD40L levels compared to uninvolved ones. In vitro sCD40L was able to prime the PMN oxidase rapidly suggesting that SCD40L could be critically involved in non-antibody-mediated TRALI (39). But, its role might not be limited to that; earlier data from our group suggested that $\mathrm{SCD} 40 \mathrm{~L}$ could induce febrile transfusion reactions by activating cyclooxygenase- 2 and thereby producing prostaglandin $\mathrm{E}_{2}$ (82). Of note, the concentrations that were required to produce $\mathrm{PGE}_{2}$ in vitro are easily met and even exceeded by one order of magnitude after transfusion of unwashed platelets. In addition, cytokine accumulation (e.g., IL-1 $\beta$, IL-6, IL-27) and accumulation of soluble OX40 ligand in the stored platelet bag has been shown to contribute to febrile non-hemolytic reactions $(83,84)$ (Figure 1). Washing and leukoreduction was protective and helped to reduce the incidence of febrile transfusion reactions (85-87). In addition to sCD40L, cytokines, and sPS, platelet-derived growth factor (PDGF) accumulates during platelet storage (88). Moreover, 
other growth factors like VEGF, FGF-2, and TGF- $\beta 1$ have been shown to accumulate during platelet storage (89-91) (Figure 1). Upon transfusion into patients with (hematologic-) malignancies, these growth factors may promote cancer growth and antagonize growth factor-targeted therapies (90). Overall, there is good reason to believe that the number of described soluble mediators is not complete; as a recent study showed the presence of 1048 proteins in the supernatant, including 69 membrane proteins (10 had been shown to be shed from platelets before). However, this data warrants further validation under storage conditions since platelets were activated with agonists instead of activating them by prolonged storage (92). We previously investigated the platelet proteome under storage conditions, using mass spectrometry and found that 117 proteins changed during storage conditions. Notably, 22 out of 117 proteins were previously described in platelets and two-thirds of these 22 were associated with alpha granules, supporting degranulation as one of the major events during storage (93).

In an intriguing study, Yazer et al. investigated if a febrile non-hemolytic transfusion reaction renders the patient more susceptible for the development of alloantibodies to subsequent red blood cell products, and found a significantly higher rate of sensitization in the study-arm (94). This result corroborated recent findings in animal models $(95,96)$ and is presumably due to cytokines in the platelet unit that are high enough to induce a febrile transfusion reaction and generate a humoral immune response which predisposes the recipient to more effective antibody production (97). The idea that transfusions could alter the immune system of the recipient other than through alloimmunization stems from the discovery that allogeneic transfusions enhanced kidney graft acceptance in transplant recipients (98). Shortly afterwards, an association between colorectal cancer recurrence and transfusion was noted and confirmed in retrospective studies (99-101). In concordance was another subsequent finding that transfusions are associated with infections perioperatively in cancer patients (102). Although all of the above mentioned initial work on transfusion-mediated immunomodulation was done on red blood cell transfusions, it is likely that soluble mediators that accumulate in platelet concentrates have an immunomodulatory effect upon transfusion into the recipient as well. Specifically, sCD40L and similar mediators could alter host defense in a way that tumor defense is impaired by shifting the immunity toward a type- 2 immune function $(103,104)$. Our group demonstrated that $\mathrm{SCD} 40 \mathrm{~L}$ stimulates $\mathrm{PGE}_{2}$ production and induces COX-2 (58, $82,105,106)$. Another possible mechanism may be that sCD40L functions as a proliferation and survival factor for the circulating leukemic cells. It is likely that washing platelet concentrates before transfusions improves survival in leukemic patients (107, 108). We were recently able to replicate our previous findings in younger patients with acute myeloid leukemia with a striking survival benefit of almost $100 \%$ in patients with favorable risk AML on a washed transfusion protocol and a short-term mortality of nearly $0 \%$ in patients with any type of AML in the treatment group (washed protocol, unpublished observations). Washing the platelet concentrate is an inexpensive and relatively easy way to get rid of the supernatant. It goes along with a mild activation and a minor loss of platelet numbers prior to transfusion. However, these modest downsides are disproportionate as compared to the potential benefits to patients in terms of survival.

Interestingly, the rate of TRALI is highest in platelet transfusions. Although it has never been convincingly demonstrated that transfused platelets are causally related to the development of TRALI, a recent discovery linked recipient platelets to the pathogenesis in antibody-mediated TRALI. Aspirin treatment and platelet depletion prevented TRALI in a mouse model (54). Furthermore, two papers linked NETs to the pathogenesis of TRALI and one of them linked the occurrence of NETs directly to platelets $(53,109)$.

\section{ABO MATCHING FOR PLATELET TRANSFUSIONS}

The ABO blood group system is still the most important system in transfusion medicine since it was first discovered by Karl Landsteiner roughly a century ago. $\mathrm{ABO}$ antigens are both integral to and passively adsorbed onto the red blood cell surface. The discovery that platelets also express ABO antigens was made in the $1950 \mathrm{~s}$ (110). More recently, they have been localized on integrins $\alpha \operatorname{IIb} \beta 3$ and $\alpha 2 \beta 1(111,112)$. One of the earliest clinical discoveries was that non-ABO-matched platelets transfusions yield a lower platelet count increment (113). This was further substantiated in multiple randomized and observational studies; in addition ABO-matched platelet transfusion protected better from bleeding and led to less frequent refractoriness (114-116). In vitro, co-incubation of A, B, or $\mathrm{AB}$ platelets with $\mathrm{O}$ plasma with differing titers of anti-A and anti-B inhibited platelet aggregation and was also associated with other anticoagulant properties, delivering a potential explanation for the reduced hemostatic activity of non-ABO-matched platelet transfusions (117). The lower platelet increment is speculatively due to clearance of antibody-coated platelets and platelets coated with immune complexes by phagocytic cells. We showed previously, that circulating $\mathrm{ABO}$ immune complexes that were isolated from patients after non-ABO-matched transfusion were able to adhere to platelets via the Fc-receptor and complement receptors, $\mathrm{cClq}$ and gC1q. In addition, in vitro formed $\mathrm{ABO}$ immune complexes showed the same ability to bind platelets via the aforementioned receptors. Inhibition of the receptors with blocking antibodies reduced the amount of bound immune complexes by $67-99 \%$. Together these findings provide an additional potential mechanism for platelet clearance after non-ABO-matched transfusion and overall for the importance of $\mathrm{ABO}$-matched transfusions clinically (118).

In a cohort trial investigating the effect of $\mathrm{ABO}$ matching platelets in patients undergoing cardiac surgery, we showed that patients who received at least one $\mathrm{ABO}$-mismatched pool of platelet had significantly longer hospital stays, more days of fever, and more RBC transfusions. Notably, recipients of ABOidentical platelets had one-quarter the mortality, fewer mean days of antibiotics and hours in the ICU than patients receiving $\mathrm{ABO}$ mismatched transfusions. Maybe due to the smaller number of patients, these latter differences were not significant (119). Our institution switched to universal ABO-matched platelet and cryoprecipitate transfusion in 2005, and this approach led to improved clinical outcomes and reduced transfusion requirements in surgical patients (120). Furthermore, this approach has also proven feasible from a blood management and administrative standpoint 
(121). Table 1 summarizes all findings from trials that were performed by our group, at our institution with regards to $\mathrm{ABO}$ matching and platelets transfusions.

\section{ALLOIMMUNIZATION TO HLA}

Patients who receive frequent platelet transfusions sometimes become less responsive to platelet transfusion, a phenomenon termed "refractoriness." There are immune-mediated mechanisms of platelet refractoriness and non-immune-mediated mechanisms. Overall, the non-immune platelet removal is more common than immune-mediated removal (122). However, in light of the focus of this review article, we will focus on the immunemediated mechanisms. The most common reason to develop immune-mediated platelet refractoriness is the development of antibodies to foreign HLA A, B (class I MHC), which are expressed on platelets and most other cell types, or the development of platelet-specific antibodies. Interestingly, in case of the sensitization to HLA antigens, transfusion of leukocyte containing blood products is associated with a higher rate of immunization, and consistently, universal leukoreduction leads to a significant reduction in platelet refractoriness (123) (Figure 1). This along with others lead to the conclusion that transfusing a small amount of leukocytes with red blood cells or platelets is more immunogenic than the transfused platelets themselves. Our institution's policy is to transfuse only leukoreduced and ABO-identical platelets, and our internal data suggest that this leads to fewer incidences of platelet refractoriness ( $<1 \%$ of patients). One potential solution when alloimmunization has occurred and refractoriness is evident is to expend the money necessary and engage in the timeconsuming process of finding an HLA-matched donor. This can be facilitated by HLA-matching or by a test that determines the antibody specificity and selects donors based on their lack of the corresponding antigens (124).

\section{PLATELET TRANSFUSION AND THROMBOSIS}

Inflammation and thrombosis are closely intertwined; it is therefore conceivable that platelet transfusions not only lead to inflammation, but also thrombosis. Indeed, there is evidence, mainly coming from an observational study, that transfusions are associated with thrombosis. A retrospective study investigated the associations between transfusions and venous thromboembolism, arterial thromboembolism, and mortality in hospitalized patients with cancer. All three outcomes were significantly more common in patients that received platelet transfusion (125). However, more studies, preferably randomized, controlled trials are needed to show this association is indeed causal. More data is available for red blood cell transfusions $(126,127)$, while overall clinical data on this subject is still rather scarce.

It is one of the issues of platelet transfusions that the hemostatic potential of the stored platelets decrease over time in the storage bag. On the other hand, the amount of soluble pro-inflammatory and pro-thrombotic mediators in the supernatant increases. These mediators presumably partially compensate for the loss of platelet function, but it is plausible that they contribute to thrombosis as well. Platelet-derived microparticles and sCD40L have been shown to be involved in thrombosis under pre-clinical, experimental conditions and are most likely amongst the culprits that mediate thrombosis (128-131).

Overall it appears, as if fresher platelets ( $<3$ days of storage) are preferable due to reduced cytokine load and are likely less

Table 1 | Studies investigating the role of ABO-group matching in platelet transfusions.

\begin{tabular}{|c|c|c|c|c|c|}
\hline Author & Study type/question & Result & Year & Journal & Reference \\
\hline Heal et al. & $\begin{array}{l}\text { In vitro study investigating the role of } \\
\text { circulating immune complexes after } \\
\text { ABO-non-identical transfusion }\end{array}$ & $\begin{array}{l}\text { Circulating immune complexes adhere to platelets via } \\
\text { Fc-receptor and complement receptors and provide a } \\
\text { potential mechanism for platelet clearance }\end{array}$ & 1996 & Vox sanguinis & (118) \\
\hline Blumberg et al. & $\begin{array}{l}\text { Retrospective cohort-study investigating } \\
\text { patients undergoing cardiac surgery }\end{array}$ & $\begin{array}{l}\text { Patients who received ABO-mismatched platelets had } \\
\text { a longer hospital stay, more fever, and more RBC } \\
\text { transfusion. Furthermore, there was a trend toward a } \\
75 \% \text { reduction in mortality with } A B O-i d e n t i c a l ~ p l a t e l e t s\end{array}$ & 2001 & Transfusion & (119) \\
\hline Refaai et al. & $\begin{array}{l}\text { Retrospective analysis of non-ABO- } \\
\text { identical platelet transfusion and the } \\
\text { effect on transfusion requirements and } \\
\text { other clinical parameters }\end{array}$ & $\begin{array}{l}\text { ABO-identical transfusions might lead to lower } \\
\text { transfusion requirements and better clinical outcome }\end{array}$ & 2011 & Vox sanguinis & $(120)$ \\
\hline Henrichs et al. & $\begin{array}{l}\text { Feasibility trial, designed to answer if } \\
\text { uniform ABO-identical platelet transfusion } \\
\text { is doable in a tertiary care hospital setting }\end{array}$ & $\begin{array}{l}\text { 97\% of patients received ABO-identical platelets. } \\
\text { There was an unexpected reduction in febrile and } \\
\text { allergic reactions. In addition, there was a reduction in } \\
\text { RBC alloimmunization and HLA platelet requirements }\end{array}$ & 2012 & Transfusion & $(121)$ \\
\hline Refaai et al. & $\begin{array}{l}\text { In vitro study investigating the effect of } \\
\text { anti-A and anti-B on platelet function and } \\
\text { clot formation }\end{array}$ & $\begin{array}{l}\text { Anti-A and anti-B inhibit platelet aggregation and } \\
\text { reduce clot formation in various in vitro assays }\end{array}$ & 2013 & Transfusion & $(117)$ \\
\hline
\end{tabular}

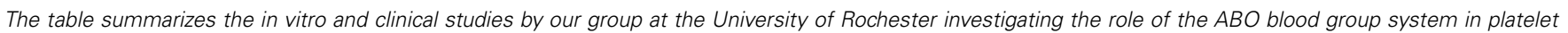
transfusions. 
pathogenic. More clinical studies are needed to evaluate the hemostatic improvement and/or impairment, as well as the thrombotic risk as a function of storage time.

\section{AUTHOR CONTRIBUTIONS}

MS and NB wrote a draft of the manuscript and revised it critically for important intellectual content. MR, SS, JH, and RP provided important feedback and revised the manuscript critically for important intellectual content. All authors approved the final version of the manuscript.

\section{ACKNOWLEDGMENTS}

Moritz Stolla received a training grant from the American Society of Hematology together with Neil Blumberg.

\section{REFERENCES}

1. Semple JW, Italiano JE Jr, Freedman J. Platelets and the immune continuum. Nat Rev Immunol (2011) 11(4):264-74. doi:10.1038/nri2956

2. Vieira-de-Abreu A, Campbell RA, Weyrich AS, Zimmerman GA. Platelets: versatile effector cells in hemostasis, inflammation, and the immune continuum. Semin Immunopathol (2012) 34(1):5-30. doi:10.1007/s00281-011-0286-4

3. van de Vijver E, De Cuyper IM, Gerrits AJ, Verhoeven AJ, Seeger K, Gutiérrez L, et al. Defects in Glanzmann thrombasthenia and LAD-III (LAD-1/v) syndrome: the role of integrin betal and beta3 in platelet adhesion to collagen. Blood (2012) 119(2):583-6. doi:10.1182/blood-2011-02-337188

4. Boulaftali Y, Hess PR, Getz TM, Cholka A, Stolla M, Mackman N, et al. Platelet ITAM signaling is critical for vascular integrity in inflammation. J Clin Invest (2013) 123(2):908-16. doi:10.1172/JCI65154

5. Aslam R, Speck ER, Kim M, Crow AR, Bang KW, Nestel FP, et al. Platelet Toll-like receptor expression modulates lipopolysaccharide-induced thrombocytopenia and tumor necrosis factor-alpha production in vivo. Blood (2006) 107(2):637-41. doi:10.1182/blood-2005-06-2202

6. Cognasse F, Hamzeh H, Chavarin P, Acquart S, Genin C, Garraud O. Evidence of Toll-like receptor molecules on human platelets. Immunol Cell Biol (2005) 83(2):196-8. doi:10.1111/j.1440-1711.2005.01314.x

7. Ståhl AL, Svensson M, Mörgelin M, Svanborg C, Tarr PI, Mooney JC, et al. Lipopolysaccharide from enterohemorrhagic Escherichia coli binds to platelets through TLR4 and CD62 and is detected on circulating platelets in patients with hemolytic uremic syndrome. Blood (2006) 108(1):167-76. doi:10.1182/blood-2005-08-3219

8. Garraud O, Berthet J, Hamzeh-Cognasse H, Cognasse F. Pathogen sensing, subsequent signalling, and signalosome in human platelets. Thromb Res (2011) 127(4):283-6. doi:10.1016/j.thromres.2010.10.015

9. Berthet J, Damien P, Hamzeh-Cognasse H, Arthaud CA, Eyraud MA, Zéni F, et al. Human platelets can discriminate between various bacterial LPS isoforms via TLR4 signaling and differential cytokine secretion. Clin Immunol (2012) 145(3):189-200. doi:10.1016/j.clim.2012.09.004

10. Koupenova M, Vitseva O, MacKay CR, Beaulieu LM, Benjamin EJ, Mick E, et al. Platelet-TLR7 mediates host survival and platelet count during viral infection in the absence of platelet-dependent thrombosis. Blood (2014) 124(5):791-802. doi:10.1182/blood-2013-11-536003

11. Boilard E, Paré G, Rousseau M, Cloutier N, Dubuc I, Lévesque T, et al. Influenza virus $\mathrm{H} 1 \mathrm{~N} 1$ activates platelets through FcgammaRIIA signaling and thrombin generation. Blood (2014) 123(18):2854-63. doi:10.1182/blood-2013-07515536

12. Rouhiainen A, Imai S, Rauvala H, Parkkinen J. Occurrence of amphoterin (HMG1) as an endogenous protein of human platelets that is exported to the cell surface upon platelet activation. Thromb Haemost (2000) 84(6):1087-94. Available from: http://th.schattauer.de/en/contents/archive/ issue/892/manuscript/2627/show.html

13. Bianchi ME. HMGB1 loves company. J Leukoc Biol (2009) 86(3):573-6. doi:10.1189/jlb.1008585

14. Tian J, Avalos AM, Mao SY, Chen B, Senthil K, Wu H, et al. Toll-like receptor 9-dependent activation by DNA-containing immune complexes is mediated by HMGB1 and RAGE. Nat Immunol (2007) 8(5):487-96. doi:10.1038/ni1457
15. Lotze MT, Tracey KJ. High-mobility group box 1 protein (HMGB1): nuclear weapon in the immune arsenal. Nat Rev Immunol (2005) 5(4):331-42. doi:10.1038/nri1594

16. Orlova VV, Choi EY, Xie C, Chavakis E, Bierhaus A, Ihanus E, et al. A novel pathway of HMGB1-mediated inflammatory cell recruitment that requires Mac-1integrin. EMBO J (2007) 26(4):1129-39. doi:10.1038/sj.emboj.7601552

17. Akbiyik F, Ray DM, Gettings KF, Blumberg N, Francis CW, Phipps RP. Human bone marrow megakaryocytes and platelets express PPARgamma, and PPARgamma agonists blunt platelet release of CD40 ligand and thromboxanes. Blood (2004) 104(5):1361-8. doi:10.1182/blood-2004-03-0926

18. Gambaryan S, Kobsar A, Rukoyatkina N, Herterich S, Geiger J, Smolenski A, et al. Thrombin and collagen induce a feedback inhibitory signaling pathway in platelets involving dissociation of the catalytic subunit of protein kinase A from an NFkappaB-IkappaB complex. J Biol Chem (2010) 285(24):18352-63. doi:10.1074/jbc.M109.077602

19. Liu F, Morris S, Epps J, Carroll R. Demonstration of an activation regulated NF-kappaB/I-kappaBalpha complex in human platelets. Thromb Res (2002) 106(4-5):199-203. doi:10.1016/S0049-3848(02)00130-5

20. Spinelli SL, Casey AE, Pollock SJ, Gertz JM, McMillan DH, Narasipura SD, et al. Platelets and megakaryocytes contain functional nuclear factor-kappaB. Arterioscler Thromb Vasc Biol (2010) 30(3):591-8. doi:10.1161/ATVBAHA.109. 197343

21. Spinelli SL, Maggirwar SB, Blumberg N, Phipps RP. Nuclear emancipation: a platelet tour de force. Sci Signal (2010) 3(144):e37. doi:10.1126/scisignal. 3144 pe 37

22. Weyrich AS, Dixon DA, Pabla R, Elstad MR, McIntyre TM, Prescott SM, et al. Signal-dependent translation of a regulatory protein, Bcl-3, in activated human platelets. Proc Natl Acad Sci U S A (1998) 95(10):5556-61. doi:10.1073/pnas.95.10.5556

23. Denis MM, Tolley ND, Bunting M, Schwertz H, Jiang H, Lindemann S, et al. Escaping the nuclear confines: signal-dependent pre-mRNA splicing in anucleate platelets. Cell (2005) 122(3):379-91. doi:10.1016/j.cell.2005.06. 015

24. Lindemann S, Tolley ND, Dixon DA, McIntyre TM, Prescott SM, Zimmerman GA, et al. Activated platelets mediate inflammatory signaling by regulated interleukin lbeta synthesis. J Cell Biol (2001) 154(3):485-90. doi:10.1083/jcb. 200105058

25. Li N. Platelet-lymphocyte cross-talk. J Leukoc Biol (2008) 83(5):1069-78. doi:10.1189/jlb.0907615

26. van Gils JM, Zwaginga JJ, Hordijk PL. Molecular and functional interactions among monocytes, platelets, and endothelial cells and their relevance for cardiovascular diseases. J Leukoc Biol (2009) 85(2):195-204. doi:10.1189/ jlb.0708400

27. Zarbock A, Polanowska-Grabowska RK, Ley K. Platelet-neutrophilinteractions: linking hemostasis and inflammation. Blood Rev (2007) 21(2):99-111. doi:10.1016/j.blre.2006.06.001

28. Smyth SS, McEver RP, Weyrich AS, Morrell CN, Hoffman MR, Arepally GM, et al. Platelet functions beyond hemostasis. J Thromb Haemost (2009) 7(11):1759-66. doi:10.1111/j.1538-7836.2009.03586.x

29. Leppanen A, White SP, Helin J, McEver RP, Cummings RD. Binding of glycosulfopeptides to P-selectin requires stereospecific contributions of individual tyrosine sulfate and sugar residues. J Biol Chem (2000) 275(50):39569-78. doi:10.1074/jbc.M005005200

30. McEver RP, Cummings RD. Perspectives series: cell adhesion in vascular biology. Role of PSGL-1 binding to selectins in leukocyte recruitment. J Clin Invest (1997) 100(3):485-91. doi:10.1172/JCI119556

31. Wang HB, Wang JT, Zhang L, Geng ZH, Xu WL, Xu T, et al. P-selectin primes leukocyte integrin activation during inflammation. Nat Immunol (2007) 8(8):882-92. doi:10.1038/nature05671

32. Evangelista V, Pamuklar Z, Piccoli A, Manarini S, Dell'elba G, Pecce R, et al. Src family kinases mediate neutrophil adhesion to adherent platelets. Blood (2007) 109(6):2461-9. doi:10.1182/blood-2006-06-029082

33. Diacovo TG, Roth SJ, Buccola JM, Bainton DF, Springer TA. Neutrophil rolling, arrest, and transmigration across activated, surface-adherent platelets via sequential action of P-selectin and the beta 2-integrin CD11b/CD18. Blood (1996) 88(1):146-57.

34. Ghasemzadeh M, Hosseini E. Platelet-leukocyte crosstalk: linking proinflammatory responses to procoagulant state. Thromb Res (2013) 131(3):191-7. doi:10.1016/j.thromres.2012.11.028 
35. Rinder HM, Bonan JL, Rinder CS, Ault KA, Smith BR. Activated and unactivated platelet adhesion to monocytes and neutrophils. Blood (1991) 78(7):1760-9.

36. Schulz C, Schäfer A, Stolla M, Kerstan S, Lorenz M, von Brühl ML, et al. Chemokine fractalkine mediates leukocyte recruitment to inflammatory endothelial cells in flowing whole blood: a critical role for P-selectin expressed on activated platelets. Circulation (2007) 116(7):764-73. doi:10. 1161/CIRCULATIONAHA.107.695189

37. Cognasse F, Hamzeh-Cognasse H, Lafarge S, Chavarin P, Cogné M, Richard Y, et al. Human platelets can activate peripheral blood B cells and increase production of immunoglobulins. Exp Hematol (2007) 35(9):1376-87. doi:10. 1016/j.exphem.2007.05.021

38. Henn V, Slupsky JR, Gräfe M, Anagnostopoulos I, Förster R, Müller-Berghaus $\mathrm{G}$, et al. CD40 ligand on activated platelets triggers an inflammatory reaction of endothelial cells. Nature (1998) 391(6667):591-4. doi:10.1038/35393

39. Khan SY, Kelher MR, Heal JM, Blumberg N, Boshkov LK, Phipps R, et al. Soluble CD40 ligand accumulates in stored blood components, primes neutrophils through CD40, and is a potential cofactor in the development of transfusionrelated acute lung injury. Blood (2006) 108(7):2455-62. doi:10.1182/blood2006-04-017251

40. Boulaftali Y, Hess PR, Kahn ML, Bergmeier W. Platelet immunoreceptor tyrosine-based activation motif (ITAM) signaling and vascular integrity. Circ Res (2014) 114(7):1174-84. doi:10.1161/CIRCRESAHA.114.301611

41. Goerge T, Ho-Tin-Noe B, Carbo C, Benarafa C, Remold-O’Donnell E, Zhao BQ, et al. Inflammation induces hemorrhage in thrombocytopenia. Blood (2008) 111(10):4958-64. doi:10.1182/blood-2007-11-123620

42. Ho-Tin-Noe B, Demers M, Wagner DD. How platelets safeguard vascular integrity. J Thromb Haemost (2011) 9(Suppl 1):56-65. doi:10.1111/j.15387836.2011.04317.x

43. Ho-Tin-Noe B, Carbo C, Demers M, Cifuni SM, Goerge T, Wagner DD. Innate immune cells induce hemorrhage in tumors during thrombocytopenia. Am J Pathol (2009) 175(4):1699-708. doi:10.2353/ajpath.2009.090460

44. Ho-Tin-Noe B, Goerge T, Wagner DD. Platelets: guardians of tumor vasculature. Cancer Res (2009) 69(14):5623-6. doi:10.1158/0008-5472.CAN-09- 1370

45. Cloutier N, Pare A, Farndale RW, Schumacher HR, Nigrovic PA, Lacroix S, et al. Platelets can enhance vascular permeability. Blood (2012) 120(6):1334-43. doi:10.1182/blood-2012-02-413047

46. Hottz ED, Lopes JF, Freitas C, Valls-de-Souza R, Oliveira MF, Bozza MT, et al. Platelets mediate increased endothelium permeability in dengue through NLRP3-inflammasome activation. Blood (2013) 122(20):3405-14. doi:10. 1182/blood-2013-05-504449

47. Zapata JC, Cox D, Salvato MS. The role of platelets in the pathogenesis of viral hemorrhagic fevers. PLoS Negl Trop Dis (2014) 8(6):e2858. doi:10.1371/ journal.pntd.0002858

48. Risitano A, Beaulieu LM, Vitseva O, Freedman JE. Platelets and platelet-like particles mediate intercellular RNA transfer. Blood (2012) 119(26):6288-95. doi:10.1182/blood-2011-12-396440

49. Massberg S, Grahl L, von Bruehl ML, Manukyan D, Pfeiler S, Goosmann C, et al. Reciprocal coupling of coagulation and innate immunity via neutrophil serine proteases. Nat Med (2010) 16(8):887-96. doi:10.1038/nm.2184

50. Ruf W, Ruggeri ZM. Neutrophils release brakes of coagulation. Nat Med (2010) 16(8):851-2. doi:10.1038/nm0810-851

51. Kraemer BF, Campbell RA, Schwertz H, Cody MJ, Franks Z, Tolley ND, et al. Novel anti-bacterial activities of beta-defensin 1 in human platelets: suppression of pathogen growth and signaling of neutrophil extracellular trap formation. PLoS Pathog (2011) 7(11):e1002355. doi:10.1371/journal.ppat.1002355

52. Clark SR, Ma AC, Tavener SA, McDonald B, Goodarzi Z, Kelly MM, et al. Platelet TLR4 activates neutrophil extracellular traps to ensnare bacteria in septic blood. Nat Med (2007) 13(4):463-9. doi:10.1038/nm1565

53. Caudrillier A, Kessenbrock K, Gilliss BM, Nguyen JX, Marques MB, Monestier $\mathrm{M}$, et al. Platelets induce neutrophil extracellular traps in transfusion-related acute lung injury. J Clin Invest (2012) 122(7):2661-71. doi:10.1172/JCI61303

54. Looney MR, Nguyen JX, Hu Y, Van Ziffle JA, Lowell CA, Matthay MA. Platelet depletion and aspirin treatment protect mice in a two-event model of transfusion-related acute lung injury. J Clin Invest (2009) 119(11):3450-61. doi:10.1172/JCI38432

55. Boudreau LH, Duchez AC, Cloutier N, Soulet D, Martin N, Bollinger J, et al. Platelets release mitochondria serving as substrate for bactericidal group IIA secreted phospholipase A2 to promote inflammation. Blood (2014) 124(14):2173-83. doi:10.1182/blood-2014-05-573543

56. Cognasse F, Hamzeh-Cognasse H, Lafarge S, Acquart S, Chavarin P, Courbil $\mathrm{R}$, et al. Donor platelets stored for at least 3 days can elicit activation marker expression by the recipient's blood mononuclear cells: an in vitro study. Transfusion (2009) 49(1):91-8. doi:10.1111/j.1537-2995.2008.01931.x

57. Kostelijk EH, Fijnheer R, Nieuwenhuis HK, Gouwerok CW, de Korte D. Soluble P-selectin as parameter for platelet activation during storage. Thromb Haemost (1996) 76(6):1086-9.

58. Kaufman J, Spinelli SL, Schultz E, Blumberg N, Phipps RP. Release of biologically active CD154 during collection and storage of platelet concentrates prepared for transfusion. J Thromb Haemost (2007) 5(4):788-96. doi:10.1111/ j.1538-7836.2007.02412.x

59. Hamzeh-Cognasse H, Cognasse F, Palle S, Chavarin P, Olivier T, Delézay $\mathrm{O}$, et al. Direct contact of platelets and their released products exert different effects on human dendritic cell maturation. BMC Immunol (2008) 9:54. doi:10.1186/1471-2172-9-54

60. Elzey BD, Schmidt NW, Crist SA, Kresowik TP, Harty JT, Nieswandt B, et al. Platelet-derived CD154 enables T-cell priming and protection against Listeria monocytogenes challenge. Blood (2008) 111(7):3684-91. doi:10.1182/blood2007-05-091728

61. André P, Prasad KS, Denis CV, He M, Papalia JM, Hynes RO, et al. CD40L stabilizes arterial thrombi by a beta3 integrin - dependent mechanism. Nat Med (2002) 8(3):247-52. doi:10.1038/nm0302-247

62. Snyder EL, Hezzey A, Katz AJ, Bock J. Occurrence of the release reaction during preparation and storage of platelet concentrates. Vox Sang (1981) 41(3):172-7. doi:10.1111/j.1423-0410.1981.tb01032.x

63. Berger G, Hartwell DW, Wagner DD. P-Selectin and platelet clearance. Blood (1998) 92(11):4446-52.

64. Michelson AD, Barnard MR, Hechtman HB, MacGregor H, Connolly RJ, Loscalzo J, et al. In vivo tracking of platelets: circulating degranulated platelets rapidly lose surface P-selectin but continue to circulate and function. Proc Natl Acad Sci U S A (1996) 93(21):11877-82. doi:10.1073/pnas.93.21.11877

65. Krishnamurti C, Maglasang P, Rothwell SW. Reduction of blood loss by infusion of human platelets in a rabbit kidney injury model. Transfusion (1999) 39(9):967-74. doi:10.1046/j.1537-2995.1999.39090967.x

66. Rank A, Nieuwland R, Liebhardt S, Iberer M, Grützner S, Toth B, et al. Apheresis platelet concentrates contain platelet-derived and endothelial cell-derived microparticles. Vox Sang (2011) 100(2):179-86. doi:10.1111/j.1423-0410.2010. 01385.x

67. Sloand EM, Yu M, Klein HG. Comparison of random-donor platelet concentrates prepared from whole blood units and platelets prepared from singledonor apheresis collections. Transfusion (1996) 36(11-12):955-9. doi:10.1046/ j.1537-2995.1996.36111297091737.x

68. Boilard E, Nigrovic PA, Larabee K, Watts GF, Coblyn JS, Weinblatt ME, et al. Platelets amplify inflammation in arthritis via collagen-dependent microparticle production. Science (2010) 327(5965):580-3. doi:10.1126/science.1181928

69. Huo Y, Schober A, Forlow SB, Smith DF, Hyman MC, Jung S, et al. Circulating activated platelets exacerbate atherosclerosis in mice deficient in apolipoprotein E. Nat Med (2003) 9(1):61-7. doi:10.1038/nm810

70. Massberg S, Brand K, Grüner S, Page S, Müller E, Müller I, et al. A critical role of platelet adhesion in the initiation of atherosclerotic lesion formation. J Exp Med (2002) 196(7):887-96. doi:10.1084/jem.20012044

71. Nomura S, Suzuki M, Katsura K, Xie GL, Miyazaki Y, Miyake T, et al. Plateletderived microparticles may influence the development of atherosclerosis in diabetes mellitus. Atherosclerosis (1995) 116(2):235-40. doi:10.1016/00219150(95)05551-7

72. Mause SF, von Hundelshausen P, Zernecke A, Koenen RR, Weber C. Platelet microparticles: a transcellular delivery system for RANTES promoting monocyte recruitment on endothelium. Arterioscler Thromb Vasc Biol (2005) 25(7):1512-8. doi:10.1161/01.ATV.0000170133.43608.37

73. Brown GT, McIntyre TM. Lipopolysaccharide signaling without a nucleus: kinase cascades stimulate platelet shedding of proinflammatory IL-1betarich microparticles. JImmunol (2011) 186(9):5489-96. doi:10.4049/jimmunol. 1001623

74. Ray DM, Spinelli SL, Pollock SJ, Murant TI, O’Brien JJ, Blumberg N, et al. Peroxisome proliferator-activated receptor gamma and retinoid $\mathrm{X}$ receptor transcription factors are released from activated human platelets and shed in 
microparticles. Thromb Haemost (2008) 99(1):86-95. doi:10.1160/TH07-050328

75. Elzey BD, Ratliff TL, Sowa JM, Crist SA. Platelet CD40L at the interface of adaptive immunity. Thromb Res (2011) 127(3):180-3. doi:10.1016/j.thromres. 2010.10.011

76. Sprague DL, Elzey BD, Crist SA, Waldschmidt TJ, Jensen RJ, Ratliff TL. Plateletmediated modulation of adaptive immunity: unique delivery of CD154 signal by platelet-derived membrane vesicles. Blood (2008) 111(10):5028-36. doi:10.1182/blood-2007-06-097410

77. Assinger A, Kral JB, Yaiw KC, Schrottmaier WC, Kurzejamska E, Wang Y, et al. Human cytomegalovirus-platelet interaction triggers toll-like receptor 2dependent proinflammatory and proangiogenic responses. Arterioscler Thromb Vasc Biol (2014) 34(4):801-9. doi:10.1161/ATVBAHA.114.303287

78. Sahler J, Woeller C, Spinelli S, Blumberg N, Phipps R. A novel method for overexpression of peroxisome proliferator-activated receptor-gamma in megakaryocyte and platelet microparticles achieves transcellular signaling. J Thromb Haemost (2012) 10(12):2563-72. doi:10.1111/jth.12017

79. Blajchman MA, Bardossy L, Carmen RA, Goldman M, Heddle NM, Singal DP. An animal model of allogeneic donor platelet refractoriness: the effect of the time of leukodepletion. Blood (1992) 79(5):1371-5.

80. Cholette JM, Henrichs KF, Alfieris GM, Powers KS, Phipps R, Spinelli SL, et al. Washing red blood cells and platelets transfused in cardiac surgery reduces postoperative inflammation and number of transfusions: results of a prospective, randomized, controlled clinical trial. Pediatr Crit Care Med (2012) 13(3):290-9. doi:10.1097/PCC.0b013e31822f173c

81. Heddle NM, Klama LN, Griffith L, Roberts R, Shukla G, Kelton JG. A prospective study to identify the risk factors associated with acute reactions to platelet and red cell transfusions. Transfusion (1993) 33(10):794-7. doi:10.1046/j.1537-2995.1993.331094054613.x

82. Phipps RP, Kaufman J, Blumberg N. Platelet derived CD154 (CD40 ligand) and febrile responses to transfusion. Lancet (2001) 357(9273):2023-4. doi:10.1016/S0140-6736(00)05108-4

83. Heddle NM, Klama L, Singer J, Richards C, Fedak P, Walker I, et al. The role of the plasma from platelet concentrates in transfusion reactions. $N$ Engl J Med (1994) 331(10):625-8. doi:10.1056/NEJM199409083311001

84. Hamzeh-Cognasse H, Damien P, Nguyen KA, Arthaud CA, Eyraud MA, Chavarin P, et al. Immune-reactive soluble OX40 ligand, soluble CD40 ligand, and interleukin-27 are simultaneously oversecreted in platelet components associated with acute transfusion reactions. Transfusion (2014) 54(3):613-25. doi:10.1111/trf.12378

85. Hetland G, Mollnes TE, Bergh K, Hogasen K, Bergerud UE, Solheim BG. Effect of filtration and storage of platelet concentrates on the production of the chemotaxins C5a, interleukin 8, tumor necrosis factor alpha, and leukotriene B4. Transfusion (1998) 38(1):16-23. doi:10.1046/j.1537-2995. 1998.38198141493.x

86. Wang RR, Triulzi DJ, Qu L. Effects of prestorage vs poststorage leukoreduction on the rate of febrile nonhemolytic transfusion reactions to platelets. Am J Clin Pathol (2012) 138(2):255-9. doi:10.1309/AJCP5H7EKZTGGBKZ

87. Vo TD, Cowles J, Heal JM, Blumberg N. Platelet washing to prevent recurrent febrile reactions to leucocyte-reduced transfusions. Transfus Med (2001) 11(1):45-7. doi:10.1046/j.1365-3148.2001.00280.x

88. Cognasse F, Boussoulade F, Chavarin P, Acquart S, Fabrigli P, Lamy B, et al. Release of potential immunomodulatory factors during platelet storage. Transfusion (2006) 46(7):1184-9. doi:10.1111/j.1537-2995.2006.00869.x

89. Kunz D, Luley C, Heim MU, Bock M. Transforming growth factor beta is increased in plasma of patients with hematologic malignancies after transfusion of platelet concentrates. Transfusion (1998) 38(2):156-9. doi:10.1046/j. 1537-2995.1998.38298193097.x

90. Kanter J, Khan SY, Kelher M, Gore L, Silliman CC. Oncogenic and angiogenic growth factors accumulate during routine storage of apheresis platelet concentrates. Clin Cancer Res (2008) 14(12):3942-7. doi:10.1158/1078-0432.CCR07- 4824

91. Mohle R, Green D, Moore MA, Nachman RL, Rafii S. Constitutive production and thrombin-induced release of vascular endothelial growth factor by human megakaryocytes and platelets. Proc Natl Acad Sci U S A (1997) 94(2):663-8. doi:10.1073/pnas.94.2.663

92. Fong KP, Barry C, Tran AN, Traxler EA, Wannemacher KM, Tang HY, et al. Deciphering the human platelet sheddome. Blood (2011) 117(1):e15-26. doi:10.1182/blood-2010-05-283838
93. Springer DL, Miller JH, Spinelli SL, Pasa-Tolic L, Purvine SO, Daly DS, et al. Platelet proteome changes associated with diabetes and during platelet storage for transfusion. J Proteome Res (2009) 8(5):2261-72. doi:10.1021/pr800885j

94. Yazer MH, Triulzi DJ, Shaz B, Kraus T, Zimring JC. Does a febrile reaction to platelets predispose recipients to red blood cell alloimmunization? Transfusion (2009) 49(6):1070-5. doi:10.1111/j.1537-2995.2009.02116.x

95. Hendrickson JE, Desmarets M, Deshpande SS, Chadwick TE, Hillyer CD, Roback JD, et al. Recipient inflammation affects the frequency and magnitude of immunization to transfused red blood cells. Transfusion (2006) 46(9):1526-36. doi:10.1111/j.1537-2995.2006.00946.x

96. Hendrickson JE, Chadwick TE, Roback JD, Hillyer CD, Zimring JC. Inflammation enhances consumption and presentation of transfused RBC antigens by dendritic cells. Blood (2007) 110(7):2736-43. doi:10.1182/blood-2007-03083105

97. Heal JM, Phipps RP, Blumberg N. One big unhappy family: transfusion alloimmunization, thrombosis, and immune modulation/inflammation. Transfusion (2009) 49(6):1032-6. doi:10.1111/j.1537-2995.2009.02182.x

98. Opelz G, Terasaki PI. Poor kidney-transplant survival in recipients with frozen-blood transfusions or no transfusions. Lancet (1974) 2(7882):696-8. doi:10.1016/S0140-6736(74)93268-1

99. Burrows L, Tartter P, Aufses A. Increased recurrence rates in perioperatively transfused colorectal malignancy patients. Cancer Detect Prev (1987) 10(56):361-9.

100. Blumberg N, Agarwal MM, Chuang C. Relation between recurrence of cancer of the colon and blood transfusion. Br Med J (1985) 290(6474):1037-9. doi:10.1136/bmj.290.6474.1037

101. Burrows L, Tartter P. Effect of blood transfusions on colonic malignancy recurrent rate. Lancet (1982) 2(8299):662. doi:10.1016/S0140-6736(82)92764-7

102. Tartter PI, Quintero S, Barron DM. Perioperative blood transfusion associated with infectious complications after colorectal cancer operations. Am J Surg (1986) 152(5):479-82. doi:10.1016/0002-9610(86)90207-2

103. Babcock GF, Alexander JW. The effects of blood transfusion on cytokine production by TH1 and TH2 lymphocytes in the mouse. Transplantation (1996) 61(3):465-8. doi:10.1097/00007890-199602150-00026

104. Kirkley SA, Cowles J, Pellegrini VD Jr, Harris CM, Boyd AD, Blumberg N. Cytokine secretion after allogeneic or autologous blood transfusion. Lancet (1995) 345(8948):527. doi:10.1016/S0140-6736(95)90627-4

105. Blumberg N, Phipps RP, Kaufman J, Heal JM. The causes and treatment of reactions to platelet transfusions. Transfusion (2003) 43(2):291-2. doi:10.1046/ j.1537-2995.2003.t01-2-00362.x

106. Blumberg N, Gettings KF, Turner C, Heal JM, Phipps RP. An association of soluble CD40 ligand (CD154) with adverse reactions to platelet transfusions. Transfusion (2006) 46(10):1813-21. doi:10.1111/j.1537-2995.2006. 00979.x

107. Blumberg N, Heal JM, Liesveld JL, Phillips GL, Rowe JM. Platelet transfusion and survival in adults with acute leukemia. Leukemia (2008) 22(3):631-5. doi:10.1038/sj.leu.2404920

108. Blumberg N, Heal JM, Rowe JM. A randomized trial of washed red blood cell and platelet transfusions in adult acute leukemia [ISRCTN76536440]. BMC Blood Disord (2004) 4(1):6. doi:10.1186/1471-2326-4-6

109. Thomas GM, Carbo C, Curtis BR, Martinod K, Mazo IB, Schatzberg D, et al. Extracellular DNA traps are associated with the pathogenesis of TRALI in humans and mice. Blood (2012) 119(26):6335-43. doi:10.1182/blood-201201-405183

110. Gurevitch J, Nelken D. ABO groups in blood platelets. Nature (1954) 173(4399):356. doi:10.1038/173356a0

111. Santoso S, Kiefel V, Mueller-Eckhardt C. Blood group A and B determinants are expressed on platelet glycoproteins IIa, IIIa, and Ib. Thromb Haemost (1991) 65(2):196-201.

112. Ogasawara K, Ueki J, Takenaka M, Furihata K. Study on the expression of ABH antigens on platelets. Blood (1993) 82(3):993-9.

113. Aster RH. Effect of anticoagulant and ABO incompatibility on recovery of transfused human platelets. Blood (1965) 26(6):732-43.

114. Pavenski K, Warkentin TE, Shen H, Liu Y, Heddle NM. Posttransfusion platelet count increments after $\mathrm{ABO}$-compatible versus $\mathrm{ABO}$-incompatible platelet transfusions in noncancer patients: an observational study. Transfusion (2010) 50(7):1552-60. doi:10.1111/j.1537-2995.2010.02602.x

115. Slichter SJ, Davis K, Enright H, Braine H, Gernsheimer T, Kao KJ, et al. Factors affecting posttransfusion platelet increments, platelet refractoriness, 
and platelet transfusion intervals in thrombocytopenic patients. Blood (2005) 105(10):4106-14. doi:10.1182/blood-2003-08-2724

116. Heal JM, Rowe JM, McMican A, Masel D, Finke C, Blumberg N. The role of ABO matching in platelet transfusion. Eur J Haematol (1993) 50(2):110-7. doi:10.1111/j.1600-0609.1993.tb00150.x

117. Refaai MA, Carter J, Henrichs KF, Davidson DC, Pollock SJ, Casey AE, et al. Alterations of platelet function and clot formation kinetics after in vitro exposure to anti-A and -B. Transfusion (2013) 53(2):382-93. doi:10.1111/j.15372995.2012.03718.x

118. Heal JM, Masel D, Blumberg N. Interaction of platelet $\mathrm{fc}$ and complement receptors with circulating immune complexes involving the AB0 system. Vox Sang (1996) 71(4):205-11. doi:10.1046/j.1423-0410.1996.7140205.x

119. Blumberg N, Heal JM, Hicks GL Jr, Risher WH. Association of ABOmismatched platelet transfusions with morbidity and mortality in cardiac surgery. Transfusion (2001) 41(6):790-3. doi:10.1046/j.1537-2995.2001. 41060790.x

120. Refaai MA, Fialkow LB, Heal JM, Henrichs KF, Spinelli SL, Phipps RP, et al. An association of $\mathrm{ABO}$ non-identical platelet and cryoprecipitate transfusions with altered red cell transfusion needs in surgical patients. Vox Sang (2011) 101(1):55-60. doi:10.1111/j.1423-0410.2010.01464.x

121. Henrichs KF, Howk N, Masel DS, Thayer M, Refaai MA, Kirkley SA, et al. Providing ABO-identical platelets and cryoprecipitate to (almost) all patients: approach, logistics, and associated decreases in transfusion reaction and red blood cell alloimmunization incidence. Transfusion (2012) 52(3):635-40. doi:10.1111/j.1537-2995.2011.03329.x

122. Levin MD, de Veld JC, van der Holt B, van ‘t Veer MB. Immune and nonimmune causes of low recovery from leukodepleted platelet transfusions: a prospective study. Ann Hematol (2003) 82(6):357-62. doi:10.1007/s00277-003-0648-7

123. Seftel MD, Growe GH, Petraszko T, Benny WB, Le A, Lee CY, et al. Universal prestorage leukoreduction in Canada decreases platelet alloimmunization and refractoriness. Blood (2004) 103(1):333-9. doi:10.1182/blood-2003-03-0940

124. Petz LD, Garratty G, Calhoun L, Clark BD, Terasaki PI, Gresens C, et al. Selecting donors of platelets for refractory patients on the basis of HLA antibody specificity. Transfusion (2000) 40(12):1446-56. doi:10.1046/j.1537-2995.2000. 40121446.x

125. Khorana AA, Francis CW, Blumberg N, Culakova E, Refaai MA, Lyman GH. Blood transfusions, thrombosis, and mortality in hospitalized patients with cancer. Arch Intern Med (2008) 168(21):2377-81. doi:10.1001/archinte. 168.21.2377
126. Tan TW, Farber A, Hamburg NM, Eberhardt RT, Rybin D, Doros G, et al. Blood transfusion for lower extremity bypass is associated with increased wound infection and graft thrombosis. J Am Coll Surg (2013) 216(5):1005-14.e2. doi:10.1016/j.jamcollsurg.2013.01.006

127. Tollefson MK, Karnes RJ, Rangel L, Carlson R, Boorjian SA. Blood type, lymphadenectomy and blood transfusion predict venous thromboembolic events following radical prostatectomy with pelvic lymphadenectomy. J Urol (2014) 191(3):646-51. doi:10.1016/j.juro.2013.10.062

128. Blumberg N, Spinelli SL, Francis CW, Taubman MB, Phipps RP. The platelet as an immune cell-CD40 ligand and transfusion immunomodulation. Immunol Res (2009) 45(2-3):251-60. doi:10.1007/s12026-009-8106-9

129. Prasad KS, Andre P, Yan Y, Phillips DR. The platelet CD40L/GP IIb-IIIa axis in atherothrombotic disease. Curr Opin Hematol (2003) 10(5):356-61. doi:10.1097/00062752-200309000-00006

130. Nomura S, Okamae F, Abe M, Hosokawa M, Yamaoka M, Ohtani T, et al. Platelets expressing P-selectin and platelet-derived microparticles in stored platelet concentrates bind to PSGL-1 on filtrated leukocytes. Clin Appl Thromb Hemost (2000) 6(4):213-21. doi:10.1177/107602960000600406

131. Siljander P, Carpen O, Lassila R. Platelet-derived microparticles associate with fibrin during thrombosis. Blood (1996) 87(11):4651-63.

Conflict of Interest Statement: The authors declare that the research was conducted in the absence of any commercial or financial relationships that could be construed as a potential conflict of interest.

Received: 03 November 2014; accepted: 14 January 2015; published online: 02 February 2015.

Citation: Stolla M, Refaai MA, Heal JM, Spinelli SL, Garraud O, Phipps RP and Blumberg N (2015) Platelet transfusion - the new immunology of an old therapy. Front. Immunol. 6:28. doi: 10.3389/fimmu.2015.00028

This article was submitted to Inflammation, a section of the journal Frontiers in Immunology.

Copyright (c) 2015 Stolla, Refaai, Heal, Spinelli, Garraud, Phipps and Blumberg. This is an open-access article distributed under the terms of the Creative Commons Attribution License (CC BY). The use, distribution or reproduction in other forums is permitted, provided the original author(s) or licensor are credited and that the original publication in this journal is cited, in accordance with accepted academic practice. No use, distribution or reproduction is permitted which does not comply with these terms. 